\title{
Fatal Leptospirosis Case in Pediatric Patient: Clinical Case
}

\author{
Laura I. Santiago García ${ }^{1}$, Citlalli Martínez Cruz ${ }^{1}$, Irma Zamudio Lugo², \\ Beatriz Rivas Sánchez ${ }^{3}$, Oscar Velasco Castrejón ${ }^{3}$, Joel Navarrete Espinosa ${ }^{1^{*}}$ \\ ${ }^{1}$ Coordination of Epidemiologic Surveillance, Unit of Public Health, IMSS, Mexico City, Mexico \\ ${ }^{2}$ Division of Hospital Epidemiologic, Children’s Hospital, CMN Century XXI, IMSS, Mexico City, Mexico \\ ${ }^{3}$ Clinic of Tropical Medicine, Unit of Experimental Medicine, School of Medicine, UNAM, Mexico

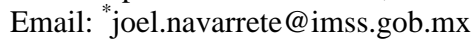

Received December 6, 2012; revised January 11, 2013; accepted January 31, 2013

\begin{abstract}
Introduction: Leptospirosis is a worldwide zoonosis. It is transmitted through the urine of infected animals. Currently, there is an increase of reports in many countries. In humans, it presents an ample clinical spectrum, which goes from an asymptomatic infection up to Weil syndrome, which is generally fatal. Clinical Case: A male, 6 years of age, who started with onset fever and jaundice, handled in private means, diagnosed as viral hepatitis " $A$ " and was referred to an institutional hospital where hepatomegaly and splenomegaly were detected. His evolution was towards graveness and, therefore, he was referred to a third level hospital with reactive Hepatitis diagnosis and to rule out lymphoma. On admission, he presented liver and kidney failure, as well as metabolic acidosis and pulmonary haemorrhage that led to death 6 hours later. Confirmatory tests for hepatitis were negative; biopsies were taken post-mortem for Leptospira diagnosis, which were positive in liver and kidney. Conclusions: Leptospirosis is a disease that may be manifested in multiple ways. It is important the understanding of this disease by the physician to improve the diagnosis and, for general population, to avoid exposure. The examination of the epidemiological history of the patient is essential.
\end{abstract}

Keywords: Leptospirosis; Fatal; Pediatric; México

\section{Introduction}

Leptospirosis is considered a cosmopolitan zoonosis that is present in both rural and urbanized areas, where environmental factors conjugate (weather, geographical area, rivers, rain, etc.) and life styles (close relations with animals) promote their development [1]. Studies performed by the International Society of Leptospirosis estimate that each year around half million cases (severe cases) of this disease are reported worldwide [2]. In Mexico, leptospirosis incidence is not exactly known because there is not existing a specific surveillance system and only some cases reported in some entities of the country are considered. However, studies performed in different populations with different techniques report prevalence that go from $10 \%$ up to $63 \%$ in the affected population [3-6].

Leptospira is a fine bacterium, 6 to $20 \mu \mathrm{m}$ length, flexible helical, with extremities as hooks, strictly aerobic, and extremely mobile; it may survive in water, alkaline soil, humid and warm environments. 250 serovares are known, grouped into 24 serogroups. This bacterium may remain for long periods in the renal tubules of ap-

\footnotetext{
${ }^{*}$ Corresponding author.
}

parently healthy animals, being excreted in the urine for many years, becoming asymptomatic carriers and favouring transmission from animal to animal or from animal to human $[1,2,7]$.

Humans are infected in a direct form (less frequent) by the contact of urine and tissue from infected animals through injured skin, especially feet or nasal and oral mucosa, or conjunctiva, and an indirect form (epidemic breakouts) through contact of stagnant water, dirt, or food contaminated with Leptospira [1].

After an incubation period of 5 to 14 days, the infection may be asymptomatic or may be manifested in an acute form, and/or become chronic. In its acute form, symptoms may be undifferentiated or mild, or present a serious condition known as Weil Syndrome, characterized by liver and kidney failure which commonly lead to death [7]. The chronic form of the infection has been known only since few years ago and it may present a large diversity of clinical manifestations, affecting, in the same way, different organs [8,9].

The lack of knowledge of the disease, its clinical behaviour and its transmission have conditioned the under registration of the infection, and, even worse, determines 
an inadequate treatment, which redounds in the increase of complications and lethality. This is especially true when we consider child population and diseases such as viral hepatitis, which presents an initial clinical frame very similar to acute leptospirosis [10,11].

The case of a pediatric patient who sought attention presenting a symptoms characterized by fever, jaundice, and hepatitis, who presented a torpid evolution that after seven days led to his death is presented. The purpose of the divulging of this information is to better the diagnosis and treatment of patients seeking medical attention due to these causes.

\section{Clinical Case}

A 6-year-old male, living in the city of Queretaro, Queretaro, Mexico, from a medium socio-economic stratum.

\subsection{Family Background}

Father, 63 years of age, with a post-degree, writer; mother, 31 years of age, finished high school, housewife. Both parents apparently healthy and living in free union. He has three siblings, 4, 3, and 1 year of age, apparently healthy.

\subsection{Pediatric-Clinical Background}

He was a first-time, high risk pregnancy product; with miscarriage threat in the fourth month. The product was obtained by eutocic delivery at 39 weeks' gestation, weighing $2250 \mathrm{~g}, 47 \mathrm{~cm}$ height, and 8/9 Apgar. He was breast-fed for 6 months, and then combined with formula until one year and a half of age, being weaned at 4 months of age. At the age of four months he was hospitalized due to a rotavirus infection. Immunization schedule was complete for his age. Blood type A (-).

\subsection{Current Condition}

Clinical condition starts on 29/05/2011 with general malaise.

On 01/06/2012 he presents fever higher to $39^{\circ} \mathrm{C}$ without schedule predominance, bilateral cervical lymph adenopathy, approximately $1 \mathrm{~cm}$, hard consistency and painful on palpation, he also presented abdominal pain. At that time he was managed with antipyretic (nimesulide) without an apparent improvement.

Two days later conjunctival jaundice, dark urine, and acolia appear, so he is taken to a private doctor who gives a diagnosis of viral hepatitis "A" and asks for laboratory tests which demonstrate alteration in liver function (Table 1) and turn positive to antibody-anti-hepatitis A: IgM and IgG (private laboratory). That same day it is decided to take him to a second-level institutional hospital in the city of Querétaro, where he is admitted with diagnoses of moderate dehydration, viral hepatitis in study to rule out bicytopenia and lymphoma. On admission, he presented Kramer IV jaundice, bilateral cervical lymphadenopathy $3 \times 2 \mathrm{~cm}$, mobile and tender to palpation, abdomen with hepatomegaly $3 \mathrm{~cm}$, and mild splenomegaly.

During his hospital stay, platelet units were transfused, as well as freshly frozen plasma. The abdominal ultrasound performed 4/06/2011 showed moderate hepatomegaly and splenomegaly; the performed serology performed in the hospital against hepatitis A, B, C, and Core was negative, as well as other studies performed for rubella, CMV (Cytomegalovirus), toxoplasmosis, coxsackie, Epstein Barr, herpes, and ECHO (enteric cytopathic human virus)

Due to the fast evolution towards graveness, on 5/06/ 2011 he was transferred to a third-level hospital in Mexico City, where he was admitted to the ICU (Intensive Care Unit).

On physical examination, hyperemic pharynx with greenish postnasal discharge was found, plus submandibular lymphadenopath of approximately $1 \mathrm{~cm}$, fixed to plans and painful on palpation, the abdomen was soft, depressible, with decreased peristalisis, and hemapatology and splenomegaly of $3 \mathrm{~cm}$ bellow the costal margin. He required tracheal intubation and central venous catheter.

Six hours after admission in the service, he presented metabolic acidosis episodes, pulmonary hemorrhage bleeding visible through the cannula, thus increasing the ventilation cycles. Chest X-rays presented effacement of the cost right diaphragmatic angle, suggesting pleural effusion.

On 06/06/2011 he presented torpid evolution with a decrease in blood pressure, unresponsive to vasopressors (dopamine), so he was handled with catecholamines (adrenaline), showing minimum response. Neurologically, the patient was at that time under barbiturateinduced coma. Hours later, heavy bleeding occurred via nasogastric tube and irreversible cardiac arrest occurred, leading to the child's death.

Due to the fact that the tests performed for hepatitis and other possible agents were negative, post-mortem samples were taken for the diagnosis of leptospirosis, which were processed in the laboratory of the Laboratorio de la Clínica de Medicina Tropical from the Unidad de Medicina Experimental at the Medicine Faculty from the Universidad Nacional Autónoma de México. Leptospira search was performed with silver staining of biopsies by Warthin Starry stain, which resulted positive in liver (Figures 1 and 2) and kidney (Figures 3 and 4), and negative in lymph node. In addition, diagnosis tests were performed to the patient's siblings, which also yielded positive results. 
Table 1. Laboratory tests performed to the patient according to the attending place.

\begin{tabular}{|c|c|c|c|c|c|}
\hline \multirow[b]{2}{*}{ Date } & \multirow{2}{*}{$\begin{array}{c}\text { Particular } \\
1.06 .2011\end{array}$} & \multicolumn{2}{|c|}{ 2nd Level Hospital } & \multicolumn{2}{|c|}{ 3rd Level Hospital } \\
\hline & & 2.06.2011 & 3.06.2011 & 5.06.2011 & 6.06.2011 \\
\hline Days of Evolution & Day 3 & Day 4 & Day 5 & Day 7 & Day 8 \\
\hline \multicolumn{6}{|c|}{ CBC } \\
\hline Hemoglobin & 14 & 13.9 & 12.10 & 11.3 & 10.6 \\
\hline Hematocrit & 41 & 40.4 & 33.40 & & 30 \\
\hline Leucocytes & 1000 & 920 & 1670 & 2200 & 3000 \\
\hline Lymphocytes & 67 & 44.8 & 33 & & 38.5 \\
\hline Neutrophiles & & 42.1 & 57.70 & 59.4 & 46.7 \\
\hline Eosinophils & & 0.1 & 0.2 & & \\
\hline Platelets & 19.000 & 2.240 & 4.520 & 30.000 & 59.000 \\
\hline MCV & & 13 & & & \\
\hline \multicolumn{6}{|c|}{ Blood Chemistry } \\
\hline Glucose & & 75 & 96 & 73 & 111 \\
\hline Urea & & & 147 & 65 & 84 \\
\hline Creatinine & & & 6 & 2 & 3 \\
\hline Uric Acid & & & 12.6 & & \\
\hline Cholesterol & & & 85 & & 82 \\
\hline Triglycerides & & & 304 & & 365 \\
\hline \multicolumn{6}{|c|}{ Bilirrubinas } \\
\hline Total Bilirubin & & 10.5 & 10.9 & 14.45 & 16.95 \\
\hline Direct Bilirubin & & 8.1 & 9.7 & 10.97 & 12.24 \\
\hline Indirect Bilirubin & & 2.4 & 2.5 & 3.98 & 4.71 \\
\hline \multicolumn{6}{|c|}{ Liver Function Tests } \\
\hline ALT & 1145 & 1408 & 3010 & 2410 & 2106 \\
\hline AST & 2571 & 4154 & 7550 & 11460 & 9976 \\
\hline LDH & & 3781 & 1211 & & \\
\hline Phosphoquinase & & 161 & 193 & & \\
\hline Alkaline Phosphatase & & & & 120 & 98 \\
\hline \multicolumn{6}{|c|}{ Serum Electorlytes } \\
\hline Calcium & 7.6 & 6.5 & & & 6.5 \\
\hline Sodium & & 127 & & 133 & 136 \\
\hline Potasium & & 5.20 & & 4.90 & 4.4 \\
\hline Chlorine & & 100 & & 98 & 99 \\
\hline Phosphorus & & 4.4 & & & \\
\hline Magnesium & & 6.6 & & & \\
\hline \multicolumn{6}{|c|}{ Hepatitis Serology } \\
\hline \multicolumn{6}{|l|}{ Antibodies } \\
\hline IgM & Positive & Negative & & & \\
\hline IgG & Negative & & & & \\
\hline
\end{tabular}




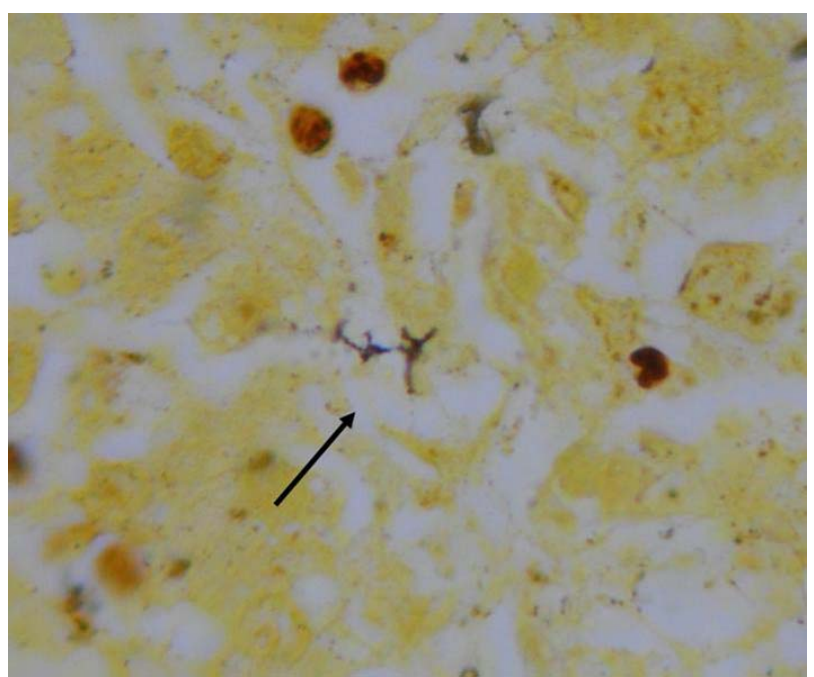

Figure 1. Leptospira in liver cut.

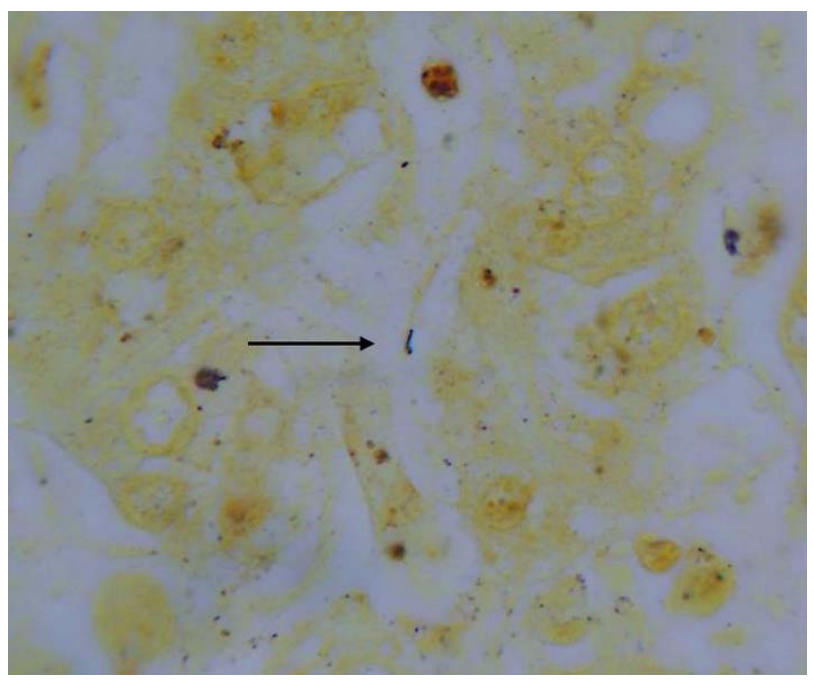

Figure 2. Leptospira in liver cut.

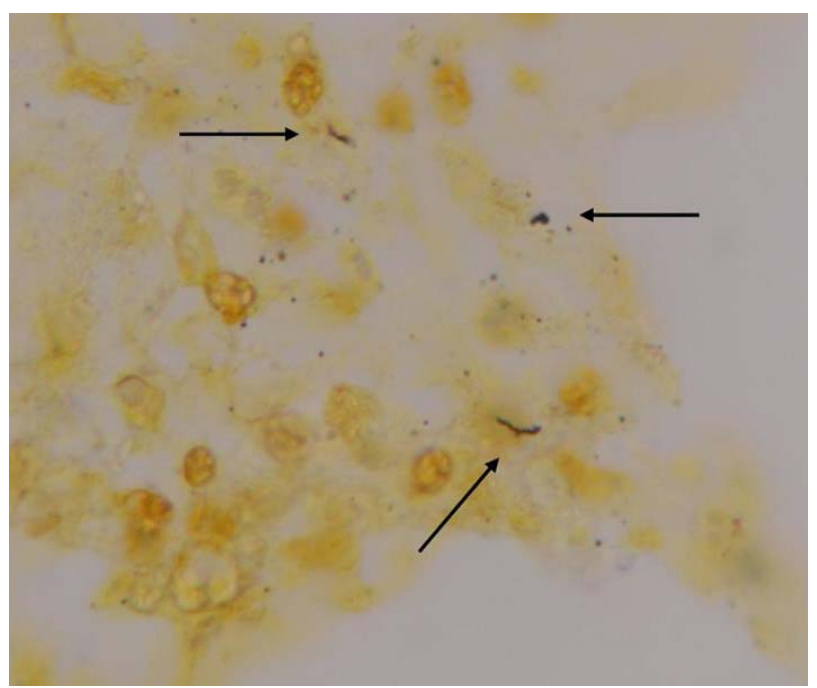

Figure 3. Leptospira in kidney cut.

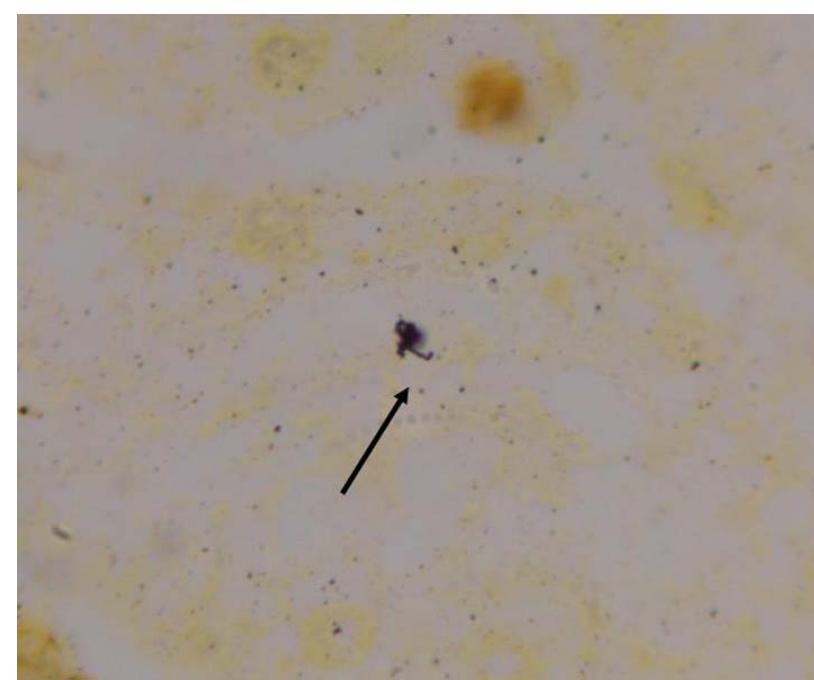

Figure 4. Leptospira in kidney cut.

\section{Discussion}

In the last decades, leptosirosis has become quite important for it has been recognized that the disease may turn acute, self-limited, or fatal, presenting a pulmonary hemorrhage or turn into chronic, being able of manifestation in multiple ways $[8,9,12]$

Even more, the knowledge of its transmission mechanism has allowed recognizing that the infection is not any more a professional disease, and it is now known that the exposure may be from the contact with infected domestic animals (dogs, cows, pigs) and wild fauna (rats), as well as with water pollutes with urine of these animals, especially when recreation activities, such as swimming, are performed or as a consequence of secondary flooding due to heavy rains; another mechanism that has been described is bad hygiene habits, such as the intake of canned food without cleaning it first [13-15].

In this sense, it is more often heard of cases initially diagnosed with several different diseases, and only after several studies they were then diagnosed as leptospirosis $[10,16]$. These facts would be unimportant if the disease were self-limited and innocuous; however, leptospirosis is an infection that entails a high risk of death if it is not timely diagnosed and treated.

Not knowing the disease and its clinical behaviour, as well as the factors that condition it, causes the doctor not to think in this possible diagnosis first, which worsens when the evolution of the disease is fast and non-specific, as in the present case in which the patient died before reaching a diagnosis.

From a medical and epidemiologic point of view, if it is true that an under registration of the infection is suspected, it is also true that leptospirosis may behave in multiple ways and may be mixed up with many diseases (Table 2), which translates in a handicap for the doctor 
when performing the diagnosis, implying a risk for the evolution of the patient.

According to the above, the epidemiologic research of these patients may be of great help to diagnose the disease correctly. In the reported case, there were data that should have been key for the diagnosis of the disease, among them, knowing the antecedent of being in contact with water in a swimming pool that did not met the necessary hygiene conditions previous to the initial clinical manifestation, as well as living closely with three dogs; these data were important, especially when the confirmatory studies for infectious Hepatitis performed in the hospital turned out negative and there was no previous antecedent of contact with similar cases that could lead to an outbreak of this viral infection. In this sense, the study of this disease is important to establish which factors determine an individual to get sick. It is noteworthy that in this case, only one of the three infected brothers suffered a severe condition, which could be related, among other factors, to the individual's immune mechanisms.

All this highlights the importance of the spreading of this information to lead the medical doctor towards this diagnosis and in this way offer a better expectation to the patient. Never the less, it is not to think in this infection early, it is necessary the implementation of laboratory tests that allow us identify on time the bacterium to be able to treat the patient correctly, especially with clinical data and laboratory parameter do not make evident great differences that aid in the diagnosis (Table 3). According to all the above, it is not redundant to mention the need to start the use of antibiotics in the first days of evolution of this infection to avoid its evolution towards graveness, justifying their use at the mere suspicion of the infection.

Table 2. Differential leptospirosis diagnosis.

\begin{tabular}{|c|c|}
\hline Acute Leptospirosis & Chronic Leptospirosis \\
\hline $\begin{array}{l}\text { - Influenza } \\
\text { - Dengue and hemorrhagic dengue } \\
\text { - Hantavirus infections, including hantavirus pulmonary syndrome or other respiratory distress syndromes } \\
\text { - } \text { Yellow fever and other viral hemorrhagic fevers } \\
\text { - } \text { Rickettsioses } \\
\text { - } \text { Borreliosis } \\
\text { - Typharia } \\
\text { - Viral hepatitis } \\
\text { - Fever of unknown origin (FUO) } \\
\text { - Toxoplasmosis. }\end{array}$ & $\begin{array}{ll}\text { - } & \text { Uveitis } \\
\text { - } & \text { Iridiociclitis } \\
\text { - } & \text { CNS alterations } \\
\text { - } & \text { Myelo-proliferative }\end{array}$ \\
\hline
\end{tabular}

Table 3. Comparison of laboratory parameters, normal values, hepatites A and patient with leptospirosis.

\begin{tabular}{ccc}
\hline Laboratory Studies & Reference & Hepatitis A \\
\hline & \multicolumn{2}{c}{ Liver Function } \\
\hline Direct Bilirrubin & $0.0-0.456 \mathrm{mg} / \mathrm{dL}$ & $>25 \mathrm{mg} / \mathrm{dL}$ (cholestatic hepatitis) \\
Transaminase Alanine Transferase & $1-30 \mathrm{mU} / \mathrm{ml}$ & $5-10$ times the normal value \\
Alkaline Phosphatase & $190-490 \mathrm{mU} / \mathrm{ml}$ & $>3$ times the normal range
\end{tabular}

CBC

$\begin{array}{lccr}\text { Leucocytes } & 4000-11,000 \mathrm{~mm}^{3} & \text { Incremento } & 16,700 \mathrm{~mm}^{3} \\ \text { Limphocytes } & 35 \%-45 \% & \text { Incremento } & 38.5 \% \\ \text { Neutrophiles } & 40 \%-50 \% & \text { Incremento } & 46.7 \% \\ \text { Hemoglobine } & 10-14 & \mathrm{~s} / \mathrm{d}^{*} & 14 \\ \text { Hematocrite } & 35-45 & \mathrm{~s} / \mathrm{d}^{*} & 41 \\ \text { Plateletes } & 200,000-300,000 & \mathrm{~s} / \mathrm{d}^{*} & 19,000-59,000\end{array}$

*No data. 
Leptospirosis is an ailment that is originated by the close relation with domestic infected animals or water contaminated with their urine; thus, exposure and infection rate of our population could be very high, which implies the intentional search for the infection in all those patients with fever and hepatitis-like data, hemorrhages, acute kidney failure, which do not fall in a specific diagnosis.

Education and promotion are important for the general population's health to avoid these risks factor that could be fatal. In the same way, the magnitude and importance of this disease justifies thinking in reinforcing a formal epidemiological surveillance for leptospirosis in Mexico, to really measure its magnitude and offer the necessary elements in taking decision in prevention and zoonosis control.

\section{REFERENCES}

[1] A. R. Bharti, J. E. Nally, J. N. Ricaldi, M. A. Matthias, M. M. Diaz, M. A. Lovett, et al., "Leptospirosis: A Zoonotic Disease of Global Importance," Lancet Infectious Diseases, Vol. 3, No. 12, 2003, pp. 757-771. doi:10.1016/S1473-3099(03)00830-2

[2] R. A. Hartskeerl, "International Leptospirosis Society: Objetives and Achievements," Revista Cubana de Medicina Tropical, Vol. 57, No. 1, 2005, pp. 7-10.

[3] I. A. Vado-Solís, M. A. Cárdenas-Marrufo, H. LaviadaMolina, F. Vargas-Puerto, J. E. B. Jiménez-Delgadillo y Zavala-Velázquez, "Estudio de Casos Clínicos e Incidencia de Leptospirosis Humana en el Estado de Yucatán, México Durante el Periodo de 1998-2000," Revista Biomédica, Vol. 13, No. 3, 2002, pp. 157-164.

[4] C. B. Leal-Castellanos, R. García-Suárez, E. GonzálezFigueroa, J. L. Fuentes-Allen and J. Escobedo-De la Peña "Risk Factors and the Prevalence of Leptospirosis Infection in a Rural Community of Chiapas, México,” Epidemiol Infect, Vol. 131, No. 3, 2003, pp. 1149-1156. doi:10.1017/S0950268803001201

[5] N. E. Joel, M. M. Maribel, R. S. Beatriz and V. C. Oscar, "Leptospirosis Prevalence in a Population of Yucatan, Mexico,” Journal of Pathogens, Vol. 2011, 2011, Article ID: 408604.

[6] G. Varela and V. J. Zavala, "Estudio Serológico de la Leptospirosis en la República Mexicana,” Revista del Instituto de Salubridad y Enfermedades Tropicales, Vol. 21, 1961, pp. 49-52.
[7] P. N. Levett, "Leptospirosis," In: Mandell, Douglas and Bennett's, Eds, Principles and Practice of Infectious Diseases, 6th Edition, Elsevier, Churchill Livingstone, 2005, pp. 2789-2795.

[8] O. Velasco-Castrejón, B. Rivas-Sánchez and H. H. RiveraReyes, "Leptospirosis Humana Crónica,” In: J. NarroRobles, O. Rivero-Serrano and J. J. López Bárcena, Eds., Diagnóstico y Tratamiento en la Práctica Médica, 2nd Edition, Manual Moderno, México, 2006, pp. 641-650.

[9] C. O. Velasco, S. B. Rivas, J. Espinoza, J. Jiménez and E. Ruiz, "Enfermedades Simuladas y Acompañantes de Leptospirosis,” Revista Cubana de Medicina Tropical, Vol. 57, No. 1, 2005, pp. 75-76

[10] M. S. Hernández, G. R. Menéndez, O. M. Torres, J. L. M. Alonso and J. M. A. Sánchez, "Leptospirosis en Niños de una Provincia Cubana,” Revista Mexicana de Pediatría, Vol. 73, No. 1, 2006, pp. 14-17.

[11] S. J. Pérez, O. J. Colin, S. A. Caballero and E. A. Cuellar, "Seropositividad a Leptospiras de Pacientes Sospechosos de Hepatitis Viral Negativos a Marcadores Serológicos," Revista Cubana de Medicina Tropical, Vol. 57, No. 1, 2005, pp. 57-58.

[12] R. T. Trevejo, P. J. G. Rigau, D. A. Ashford, E. M. McClure, G. C. Jarquin, J. J. Amador, et al., "Epidemic Leptospirosis Associated with Pulmonary Hemorrhage-Nicaragua 1995," The Journal of Infectious Diseases, Vol. 178, No. 5, 1998, pp. 1457-1463. doi:10.1086/314424

[13] C. Manuel, T. Rafael, B. Lourdes, G. Dana, G. Martha and V. J. M. Brote de, "Leptospirosis Asociado a la Natación en una Fuente de Agua Subterránea en Una Zona Costera, Lima-Perú,” Revista Peruana de Medicina Experimental y Salud Pública, Vol. 26, No. 4, 2009, pp. 441-448.

[14] J. Pradutkanchana, S. Pradutkanchana, M. Kemapanmanus, N. Wuthipum and Silpapajakul, "The Etiology of Acute Pirexia of Unknown Origin in Children after a Flood,” The Southeast Asian Journal of Tropical Medicine and Public Health, Vol. 34, No. 1, 2003, pp. 175-178.

[15] E. J. Sanders, J. G. Rigau-Perez, H. L. Smits, C. C. Deseda, V. A. Vorndam, T. Aye, et al.. "Increase of Leptospirosis in Dengue Negative Patients after a Hurricane in Puerto Rico in 1966," The American Journal of Tropical Medicine and Hygiene, Vol. 61, No. 3, 1999, pp. 399404.

[16] O. Velasco-Castrejón, B. Rivas-Sánchez, E. Gutiérrez, L. Chávez, P. Duarte, S. Chavarría, et al., "Leptospira Simulador o Causante de Leucemia?” Revista Cubana de Medicina Tropical, Vol. 57, No. 1, 2005, pp. 17-24. 